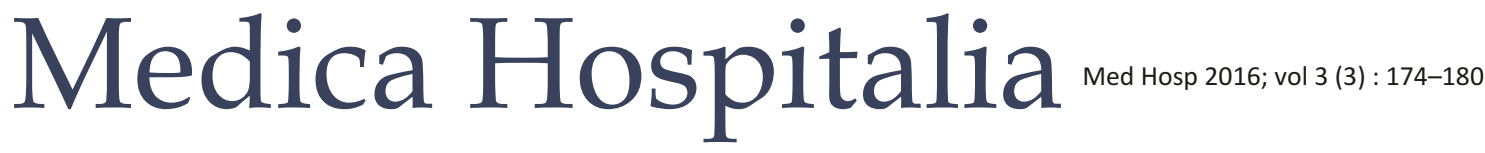

Original Article

\section{Hubungan Pola Makan dengan Pola Defekasi Pada Siswa Kelas V dan Kelas VI Sekolah Dasar di Semarang}

\author{
Ersalina Liviani $G^{1}$, Ninung RD Kusumawati², Maria Mexitalia ${ }^{2}$ \\ ${ }^{1}$ Mahasiswa program pendidikan S-1 Pendidikan Dokter Fakultas Kedokteran Universitas Diponegoro \\ ${ }^{2}$ Departemen IImu Kesehatan Anak Fakultas Kedokteran Universitas Diponegoro/RSUP Dr. Kariadi, Semarang
}

\begin{abstract}
Abstrak
Latar belakang : Pola makan yang tidak tepat menjadi salah satu penyebab masalah kesehatan anak usia sekolah. Pola makan sangat berpengaruh terhadap pola defekasi. Pola makan anak zaman sekarang cenderung mengkonsumsi makanan tinggi kalori dan rendah serat. Serat dan cairan sangat berpengaruh dalam proses defekasi. Kekurangan serat dan cairan menyebabkan penurunan frekuensi buang air besar (BAB) dan konsistensi feces keras sehingga sulit dikeluarkan. Penelitian ini bertujuan membuktikan adanya hubungan pola makan, terutama asupan serat dan cairan terhadap pola defekasi dinilai dari frekuensi BAB dan konsistensi feces.

Metode : Penelitian observasional dengan desain cross-sectional. Sampel sebanyak 70 responden yang memenuhi kriteria inklusi dan eksklusi diwawancara pola makannya melalui food recall $2 \times 24$ jam sebanyak 3 kali dan diminta untuk mengisi kuesioner pola BAB selama 1 minggu. Data dideskripsikan dalam bentuk tabel. Analisa analitik dilakukan dengan SPSS for Windows 17.0.

Hasil : Rata-rata asupan serat responden 9,3 gr per hari. Rata-rata asupan cairan responden $1723,75 \mathrm{ml}$ per hari. Rata-rata frekuensi $B A B$ responden yaitu sebanyak 4 kali/minggu. 58,6\% responden memiliki konsistensi feces normal, 28,3\% keras, dan $17,1 \%$ cair. Tidak terdapat hubungan yang signifikan antara asupan serat dengan frekuensi $\operatorname{BAB}(p=0,060)$ dan konsistensi feces $(p=0,160)$. Terdapat hubungan yang signifikan antara asupan cairan dengan frekuensi $\mathrm{BAB}(p<0,001)$ dan konsistensi feces $(p=0,001)$.

Simpulan : Terdapat hubungan yang signifikan antara asupan cairan dengan frekuensi BAB dan konsistensi feces. Semakin sedikit asupan cairan semakin jarang frekuensi $B A B$ dan semakin keras konsistensi tinja. Tidak terdapat hubungan yang signifikan antara asupan serat dengan frekuensi BAB dan konsistensi feces.
\end{abstract}

Kata Kunci : Serat, Cairan, Frekuensi BAB, Konsistensi feces

\section{Correlation of dietary habits to bowel pattern in $5^{\text {th }}$ and $6^{\text {th }}$ graders primary school in Semarang}

\section{Abstract}

Background : Improper dietary habit becomes one of the causes of school age children's health problem. Dietary habit affects toileting habit. Dietary habit of school age children nowadays tends to have high calories diet and lacks of fiber. Dietary fiber and fluid intake have a great role in bowel movements. Lack of dietary fiber and fluid intake decreasing defecation frequency and increasing stool consistency which causing the stool is difficult to remove. This study aimed to prove the correlation between dietary fiber and fluid intake with defecation pattern among school age children.

Methods : Observational study with cross-sectional design. 70 samples which include in inclusion and exclusion criteria were interviewed using food recall $2 \times 24$ hour method for 3 times and asked to complete the 1 week bowel pattern questionnaire. Data was described in table. Analytical analysis was processed using SPPS for windows 17.00

Results : The average dietary fiber intake was $9,3 \mathrm{gr} /$ day. The average fluid intake was $1723.25 \mathrm{ml} /$ day. The average of defecation frequency was 4 times per week. $58,6 \%$ of samples have normal stool consistency, while $28.3 \%$ have hard and $17.1 \%$ have watery stool consistency. There was no significant correlation between dietary fiber intake with defecation frequency $(p=0.060)$ and stool consistency $(p=0.160)$. There was significant correlation between fluid intake with defecation frequency $(p<0.001)$ and stool consistency $(p=0.001)$.

Conclusion : There was significant correlation between fluid intake with defecation frequency and stool consistency. Lower in fluid intake leads to decrease in defecation frequency and harder stool consistency. There was no significant correlation between dietary fiber intake with defecation frequency and stool consistency.

Keywords : Dietary fiber, fluid intake, defecation frequency, stool consistency 


\section{PENDAHULUAN}

Salah satu penyebab munculnya masalah kesehatan pada anak usia sekolah dasar adalah pola makan yang tidak tepat. Anak usia sekolah dasar membutuhkan makanan yang banyak mengandung energi untuk dapat menunjang aktivitasnya. Tidak hanya asupan energi yang harus diperhatikan, keseimbangan gizi yang didapat melalui pola makan yang sehat perlu diperhatikan, termasuk asupan serat dan cairan. ${ }^{1}$

Pola makan sangat berpengaruh terhadap pola defekasi. Kelainan pola makan dapat menyebabkan kelainan pola defekasi. ${ }^{2}$ Istilah pola defekasi itu sendiri mencakup frekuensi defekasi dan konsistensi tinja (feces). ${ }^{3}$

Kelainan pola defekasi yang ditandai dengan peningkatan frekuensi defekasi melebihi 3 kali dalam sehari disertai dengan penurunan konsistensi feces disebut diare. Diare dapat menjadi manifestasi klinis penyakit yang diderita anak, misalnya infeksi, keracunan makanan, malabsorbsi, alergi makanan, dan lain sebagainya. ${ }^{4}$

Kelainan pola defekasi yang lainnya yaitu konstipasi. Konstipasi adalah evakuasi feces yang jarang atau sulit. ${ }^{5}$ Ilmuwan menyatakan berbagai versi definisi defekasi, namun, belum ada kesepakatan tentang batasan konstipasi itu sendiri. Definisi konstipasi menurut Ikatan Dokter Anak Indonesia (IDAI) adalah ketidakmampuan melakukan evakuasi tinja secara sempurna, yang tercermin dari 3 aspek, yaitu berkurangnya frekuensi berhajat dari biasanya, tinja yang lebih keras dari sebelumnya, dan pada palpasi abdomen teraba masa tinja (skibala) dengan atau tidak disertai enkopersis (kecepirit). ${ }^{6}$ Konstipasi pada anak usia sekolah dasar biasanya disebabkan karena kesalahan pola makan yang kurang mengkonsumsi serat dan cairan.

Serat makanan berfungsi meningkatkan cairan pada konsistensi feces, dan mempunyai efek laksatif yang besar, serta dapat meningkatkan massa feces sehingga dapat meningkatkan frekuensi buang air besar. ${ }^{7,8}$ Kekurangan serat dapat menyebabkan proses pengeluaran feces yang tidak normal, dan berakhir pada konstipasi dan masalah saluran pencernaan lainnya yang dapat mengganggu aktivitas sehari-hari. Sayangnya hasil penelitian melaporkan bahwa diperkirakan 50\% orang tua anak sering tidak mengenali tanda-tanda awal anak mengalami konstipasi sampai terjadilah konstipasi kronik. ${ }^{9}$

Jumlah asupan serat yang dianjurkan untuk anak laki-laki usia 10-12 tahun yaitu $30 \mathrm{~g}$ per hari dan anak perempuan usia 10-12 tahun yaitu 28 g per hari. ${ }^{10}$ Sedangkan asupan cairan yang dianjurkan bagi anak laki-laki usia 9-13 tahun yaitu $2400 \mathrm{ml}$ per hari, dan bagi anak perempuan usia 9-13 tahun yaitu $2100 \mathrm{ml}$ per hari. ${ }^{11}$

Data mengenai perilaku konsumsi sayur dan buah pada anak usia di bawah 10 tahun di Indonesia masih sangat sulit didapatkan. Riset Kesehatan Dasar 2013 melaporkan bahwa $80 \%$ penduduk Indonesia di atas usia 10 tahun cenderung memiliki perilaku kurang makan sayur dan buah. Angka ini tidak mengalami perubahan yang berarti jika dibandingkan dengan, hasil yang didapatkan dari Riset Kesehatan Dasar yang dilakukan pada tahun 2007. ${ }^{12}$

Berdasarkan uraian di atas, penulis ingin melakukan penelitian mengenai hubungan pola makan terhadap pola defekasi pada anak kelas V dan kelas VI sekolah dasar di Semarang. Hal ini dikarenakan kelainan pola defekasi sangat dipengaruhi oleh pola makan dan kelainan dapat menimbulkan gangguan pada anak usia sekolah dasar untuk dapat melakukan aktivitasnya sehari-hari.

Tujuan dari penelitian ini adalah menganalisis hubungan pola makan, khususnya asupan serat dan cairan dengan pola defekasi yang dilihat melalui frekuensi buang air besar dan konsistensi feces pada siswa kelas V dan kelas VI sekolah dasar. Hasil penelitian diharapkan dapat memberi informasi bagi masyarakat tentang asupan serat dan cairan pada siswa kelas $\mathrm{V}$ dan kelas VI SD dan sumber informasi bagi penelitian selanjutnya.

\section{METODE}

Penelitian ini merupakan penelitian observasional dengan desain cross-sectional. Penelitian ini akan dilakukan pada siswa kelas V dan kelas VI, Semarang pada awal April akhir Mei 2015.

Penelitian ini melibatkan 82 siswa kelas $\mathrm{V}$ dan kelas VIdiminta untuk mengisi kuesioner Screening for Children Anxiety Related Disorder C (SCARED-C) untuk screening adanya gangguan cemas, kemudian diwawancara pola makannya dengan menggunakan metode food recall 2x24 jam yang dilakukan selama 3 kali dan diminta untuk mengisi kuesioner pola defekasi Bristol Stool Chart selama 1 minggu. 70 siswa memenuhi kriteria inklusi dan eksklusi. Kriteria inklusi yaitu siswa kelas V dan kelas VI bersedia menjadi responden dalam penelitian ini, dan mendapat informed consent dari orang tua siswa. Kriteria eksklusi yaitu siswa yang tidak hadir pada saat pengambilan data pertama kali dan memiliki skor kuesioner SCARED-C $>25$.

Data asupan serat dikategorikan menjadi 3, yaitu kurang (<25 gr/hari), cukup (25-30 gr/hari), dan lebih (>30 gr/hari). ${ }^{11}$ Data asupan cairan dikategorikan menjadi kurang ( $<1800 \mathrm{ml} /$ hari) dan cukup $(\geq 1800$ $\mathrm{ml} /$ hari) ${ }^{10}$ Data frekuensi buang air besar dikategorikan menjadi 3, yaitu $>3$ kali dalam 1 hari, $<3$ kali dalam 1 minggu, dan $\geq 3$ kali dalam 1 minggu. ${ }^{6}$ Data konsistensi feces berdasarkan Bristol Stool Chart (7 tipe) menjadi 3 kategori, yaitu keras (tipe 1 dan 2), normal (tipe 3 dan 4), dan cair (tipe 5, 6, dan 7). ${ }^{13}$ Data yang dikumpulkan 
adalah data primer yang diperoleh dari wawancara dan pengisian kuesioner. Data dianalisa dengan menggunakan uji Chi-Square.

\section{HASIL}

Penelitian ini telah dilakukan pada siswa kelas $\mathrm{V}$ dan kelas VI di 3 sekolah dasar di kecamatan Gajah Mungkur, Semarang. Cara pemilihan sampel adalah multi stages random sampling. Sampel dipilih yang memenuhi kriteria inklusi dan eksklusi dimulai dari awal April s/d akhir Mei 2015. Selama rentang waktu penelitian, didapatkan 82 siswa yang memenuhi kriteria inklusi dan 12 siswa tersingkir oleh karena kriteria eksklusi. Seluruh siswa dimintai kesediaannya untuk menjadi responden penelitian ini dan memberi tahu orang tuanya untuk memberikan persertujuan melalui pengisian informed consent 1 minggu sebelum pengambilan data. Seluruh siswa diminta untuk mengisi kuesioner SCARED-C kemudian diwawancara food recall $2 \times 24$ jam sebanyak 3 kali dan diminta mengisi kuesioner Bristol Stool Chart selama 1 minggu. 70 siswa terpilih menjadi sampel dalam penelitian ini.
Rerata umur responden penelitian adalah 10,93 dengan 31 responden laki-laki $(44,3 \%)$ dan 39 responden perempuan $(55,7 \%)$. Rerata asupan serat responden 9,30 gr/hari dan rerata asupan cairan responden 1723,75 $\mathrm{ml} /$ hari masih berada pada kategori kurang dari Angka Kecukupan Gizi yang dibutuhkan anak usia 9-13 tahun di Indonesia. ${ }^{10}$ Seluruh data asupan serat dalam penelitian ini berada pada kategori kurang, kemudian dilakukan pengkategorian ulang sesuai dengan anjuran Mahan dan Escott (2008) menjadi sangat kurang $(<10$ gr/hari) dan kurang (10-24 gr/hari). ${ }^{14}$

Tabel 3 dan 4 menunjukkan bahwa 62,9\% memiliki asupan serat sangat kurang dan asupan cairan cukup.

\begin{tabular}{|c|c|c|}
\hline \multicolumn{3}{|c|}{ Jenis kelamin subjek penelitian } \\
\hline Jenis Kelamin & Frekuensi & $\%$ \\
\hline Laki-laki & 31 & 44,3 \\
\hline Perempuan & 39 & 55,7 \\
\hline
\end{tabular}

\begin{tabular}{|c|c|c|c|}
\hline Variabel & Mean \pm SD & Median & Minimum - Maksimum \\
\hline Usia & $10,93 \pm 0,87$ & 11 & $10-14$ \\
\hline Tinggi Badan (cm) & $141,18 \pm 7,39$ & 140,85 & $123,90-158,10$ \\
\hline Berat Badan (kg) & $36,68 \pm 10,14$ & 35,30 & $23,6-67,30$ \\
\hline Asupan Energi per hari (kkal) & $1605,52 \pm 413,23$ & 1536,43 & $1020,70-3574,63$ \\
\hline Asupan Karbohidrat per hari (gr) & $228,16 \pm 58,56$ & 215,09 & $129,30-383,51$ \\
\hline Asupan Protein per hari (gr) & $56,89 \pm 19,88$ & 54,01 & $24,70-170,02$ \\
\hline Asupan Lemak per hari (gr) & $45,59 \pm 19,72$ & 40,30 & $17,70-172,18$ \\
\hline Asupan Serat per hari (gr) & $9,30 \pm 3,87$ & 8,75 & $2,00-20,50$ \\
\hline Asupan cairan per hari (ml) & $1723,75 \pm 457,06$ & 1686,05 & $650,00-4596,80$ \\
\hline
\end{tabular}

\section{TABE 13}

\section{Distribusi data asupan serat per hari}

\section{Asupan Serat}

Sangat Kurang $(<10$ gr per hari)

Kurang (10-24 gr per hari)

Total

\section{Frekuensi}

(\%)

\section{4}

26

70
62,9

37,1

100 
TABEL 4

Distribusi data asupan cairan per hari

Asupan Cairan

Kurang (<1800ml per hari)

Cukup ( $\geq 1800 \mathrm{ml}$ per hari)

Total
Frekuensi

44

26

70
(\%)

62,9

37,1

100

\section{TABBEL 5}

Distribusi frekuensi BAB responden

\begin{tabular}{lccc} 
& & Frekuensi BAB responden \\
& $\mathbf{> 3}$ kali dalam 1 hari & $<\mathbf{3}$ kali dalam 1 minggu & $\mathbf{2 3}$ kali dalam 1 minggu \\
\hline Jumlah & 0 & 20 & 50 \\
Prosentase (\%) & 0 & 28,6 & 71,4 \\
\hline
\end{tabular}

\section{TABEL 6}

Distribusi konsistensi feces responden

\begin{tabular}{lcccc} 
& Keras & Konsistensi feces \\
& Normal & Cair & Total \\
\hline Frekuensi & 17 & 41 & 12 & 70 \\
Prosentase (\%) & 28,3 & 58,6 & 17,1 & 100 \\
\hline
\end{tabular}

\section{TABEL 7}

\section{Hubungan asupan serat dengan frekuensi BAB}

\begin{tabular}{|c|c|c|c|c|c|}
\hline \multirow{3}{*}{ Asupan Cairan } & \multicolumn{4}{|c|}{ Frekuensi BAB } & \multirow[t]{3}{*}{$\boldsymbol{p}$} \\
\hline & \multicolumn{2}{|c|}{$<3$ kali per minggu } & \multicolumn{2}{|c|}{$\geq 3$ kali per minggu } & \\
\hline & $n$ & $\%$ & $n$ & $\%$ & \\
\hline Sangat Kurang (<10 gr per hari) & 16 & 80 & 28 & 56 & 0,060 \\
\hline Kurang (10-24 gr per hari) & 4 & 20 & 22 & 44 & \\
\hline
\end{tabular}

Uji Chi-Square

Tabel 5 menunjukkan tidak terdapat responden yang buang air besar $>3$ kali dalam 1 minggu, sebagian besar $(71,4 \%)$ responden memiliki frekuensi buang air besar $\geq 3$ kali dalam 1 minggu dengan rerata frekuensi buang air besar $4 \mathrm{kali} /$ minggu. Tabel 6 menunjukkan distribusi konsistensi tinja responden.

Tabel 7 menunjukkan tidak terdapat hubungan antara asupan serat dengan frekuensi BAB, dengan hasil $p=0,06(p>0,05)$. Tabel 8 menunjukkan tidak terdapat hubungan antara asupan serat dengan konsistensi feces dengan hasil $p=0,160(p>0,05)$.

Tabel 9 menunjukkan terdapat hubungan antara asupan cairan dengan frekuensi $\mathrm{BAB}$ dengan nilai $p<0,05$. Semakin sedikit asupan cairan, maka semakin jarang frekuensi BAB.

Tabel 10 menunjukkan terdapat hubungan antara asupan cairan dengan konsistensi feces, dengan nilai $p=0,001(p<0,05)$. Semakin sedikit asupan cairan, maka 


\begin{tabular}{|c|c|c|c|c|c|c|c|}
\hline \multicolumn{8}{|c|}{ Hubungan asupan serat dengan konsistensi feces } \\
\hline \multirow{3}{*}{ Asupan Serat } & \multicolumn{6}{|c|}{ Konsistensi feces } & \multirow[t]{3}{*}{$p$} \\
\hline & \multicolumn{2}{|c|}{ Keras } & \multicolumn{2}{|c|}{ Normal } & \multicolumn{2}{|c|}{ Cair } & \\
\hline & $n$ & $\%$ & $n$ & $\%$ & $n$ & $\%$ & \\
\hline Sangat Kurang (<10 gr per hari) & 13 & 76,5 & 26 & 63,4 & 5 & 41,7 & 0,160 \\
\hline Kurang (10-24 gr per hari) & 4 & 23,5 & 15 & 36,6 & 7 & 58,3 & \\
\hline
\end{tabular}

Uji Chi-Square

TABEL 9

Hubungan asupan cairan dengan frekuensi BAB

\begin{tabular}{|c|c|c|c|c|c|}
\hline \multirow{3}{*}{ Asupan Cairan } & \multicolumn{4}{|c|}{ Frekuensi BAB } & \multirow[t]{3}{*}{$\boldsymbol{p}$} \\
\hline & \multicolumn{2}{|c|}{$<3$ kali dalam 1 minggu } & \multicolumn{2}{|c|}{$\geq 3$ kali dalam 1 minggu } & \\
\hline & $n$ & $\%$ & $n$ & $\%$ & \\
\hline Kurang (<1800 ml per hari) & 19 & 95 & 25 & 50 & $<0,001$ \\
\hline Cukup ( $\geq 1800 \mathrm{ml}$ per hari) & 1 & 5 & 25 & 50 & \\
\hline
\end{tabular}

Uji Chi-Square

TABEL 10

Hubungan asupan cairan dengan konsistensi feces

\begin{tabular}{|c|c|c|c|c|c|c|c|}
\hline \multirow{3}{*}{ Asupan Cairan } & \multicolumn{6}{|c|}{ Konsistensi feces } & \multirow[t]{3}{*}{$p$} \\
\hline & \multicolumn{2}{|c|}{ Keras } & \multicolumn{2}{|c|}{ Normal } & \multicolumn{2}{|c|}{ Cair } & \\
\hline & $n$ & $\%$ & $n$ & $\%$ & $n$ & $\%$ & \\
\hline Kurang (<1800 ml per hari) & 16 & 94,1 & 25 & 61 & 3 & 25 & 0,001 \\
\hline Cukup ( $\geq 1800 \mathrm{ml}$ per hari) & 1 & 5,9 & 16 & 39 & 9 & 75 & \\
\hline
\end{tabular}

Uji Chi-Square

semakin keras dan kering konsistensi feces.

\section{PEMBAHASAN}

Serat merupakan komponen penting yang dapat mempengaruhi proses buang air besar karena dapat membentuk massa feces dan meningkatkan motilitas usus sehingga dapat memperlancar proses buang air besar. Penelitian sebelumnya menunjukkan adanya hubungan bermakna antara asupan serat dengan frekuensi BAB 2,3 dan hubungan bermakna antara asupan cairan dengan konsistensi tinja. ${ }^{2}$ Semakin tinggi asupan serat, maka semakin tinggi frekuensi buang air besar dan semakin cair konsistensi tinja.

Data yang didapatkan dalam penelitian ini menunjukkan rerata asupan serat yang dikonsumsi sehari-hari anak kelas V dan kelas VI sekolah dasar sebesar 9,3 gr per hari. Angka ini masih jauh di bawah dari angka yang dianjurkan dalam Food and Nutrition Board, Institute of Medicine, National Academics $(<25 \mathrm{gr} /$ hari $),{ }^{11}$ juga termasuk ke dalam kategori kurang menurut AKG orang Indonesia untuk anak usia 9-13 tahun, yaitu sebesar 28 gr per hari. ${ }^{10} \mathrm{Hal}$ ini bisa disebabkan oleh karena lokasi pengambilan sampel hasil dari randomisasi dengan metode multi stages random sampling hanya pada lokasi di pusat kota Semarang, dimana banyak penelitian sebelumnya menunjukkan bahwa pola makan anak terutama pada pusat kota pada zaman sekarang lebih banyak mengkonsumsi makanan tinggi kalori dan rendah serat.,12,15 Semua data asupan serat yang kurang ini kemudian dalam penelitian ini dikategorikan menjadi 2 menurut kriteria yang dibuat oleh Mahan dan Escott (2008), yaitu menjadi kategori sangat kurang (<10 gr per hari) dan kategori kurang 
(10-24 gr per hari)..$^{14}$

Tidak terdapatnya hubungan antara asupan serat baik dengan frekuensi $\mathrm{BAB}$ maupun dengan konsistensi tinja dalam penelitian dapat disebabkan oleh adanya bias pada saat wawancara food recall $2 \times 24$ jam sehingga mempengaruhi hasil pengukuran asupan serat per hari yang dikonsumsi oleh responden.

Anak cenderung kurang dapat mengingat porsi dari makanan yang mereka makan. Anak yang berusia lebih muda lebih cenderung mengingat porsi makanan lebih sedikit dari yang ia makan sehingga akan mempengaruhi jumlah asupan dari komponenkomponen makanan dari makanan yang ia makan. ${ }^{16}$ Kemungkinan adanya flat-slope syndrome, suatu kecenderungan responden yang kurus untuk melaporkan porsi makanan lebih besar dari yang dikonsumsinya, serta sebaliknya responden yang gemuk untuk melaporkan porsi makanan lebih sedikit dari yang dikonsumsinya, juga dapat menyebabkan adanya bias dalam wawancara food recall. ${ }^{17}$

Penelitian ini juga tidak meneliti tentang jenis serat yang dikonsumsi oleh responden. Serat secara garis besar dibagi menjadi 2, yaitu serat larut dan serat tidak larut. Serat larut yang biasa disebut soluble fiber memperlambat proses penyerapan makanan dan pencernaan makanan, sedangkan serat tidak larut yang biasa disebut insoluble fiber menyerap air lebih banyak dalam usus sehingga memperlancar proses pencernaan dan pergerakan makanan untuk dikeluarkan. Serat larut banyak terdapat pada brokoli, wortel, kacang kedelai, pisang, kulit apel, bawang, dan lain-lain. Serat tidak larut banyak pada kacang hijau, kacang-kacangan, kiwi, anggur, tomat, kembang kol, sayur-sayuran hijau, dan lain-lain. ${ }^{18,19}$

Penelitian ini juga tidak meneliti tentang komposisi dari mikroba dari usus responden. Mikroba usus yang bersifat simbiosis mutualisme dengan manusia mempengaruhi fungsi saluran pencernaan sehingga juga mempengaruhi pola defekasi. Semakin tinggi komposisi mikroba usus, semakin baik fungsi motorik dan sensorik usus. ${ }^{20,21}$

Asupan cairan juga berperan dalam proses defekasi. Penelitian sebelumnya yang dilakukan oleh Miguel A S, dkk pada tahun sebelumnya menunjukkan adanya hubungan antara asupan cairan dengan frekuensi $\mathrm{BAB}$, dimana frekuensi $\mathrm{B} A \mathrm{~B}$ meningkat pada orang yang mengkonsumsi asupan cairan yang tinggi. ${ }^{2}$

Data rerata asupan cairan pada penelitian ini yaitu sebesar1723,75 \pm 457,06 ml per hari. Angka ini masih masuk ke dalam kriteria kurang untuk anak usia 9-13 tahun menurut angka kecukupan gizi yang dibutuhkan orang Indonesia $(1800 \mathrm{ml}){ }^{10}$ Pada penelitian ini didapatkan hasil terdapat hubungan bermakna $(p<0,05)$ antara asupan cairan dengan frekuensi $\mathrm{BAB}$ dan hubungan bermakna $(p<0,05)$ antara asupan cairan dengan konsistensi feces.
Hasil penelitian ini sesuai dengan penelitian yang sudah pernah dilakukan oleh Miguel AS, dkk, dimana dikatakan frekuensi buang air besar semakin meningkat pada orang dengan asupan cairan yang tinggi.

\section{SIMPULAN}

Peneltian ini menyimpulkan bahwa rerata asupan serat dan cairan siswa kelas V dan kelas VI Sekolah Dasar di Semarang berada pada kurang dari yang dianjurkan AKG orang Indonesia untuk usia 9-13 tahun serta tidak terdapat hubungan antara asupan serat dengan frekuensi buang air besar dan konsistensi feces, terdapat hubungan antara asupan cairan dengan frekuensi buang air besar dan konsistensi feces, dimana semakin sedikit asupan cairan yang dikonsumsi, semakin jarang frekuensi buang air besar dan semakin keras konsistensi feces yang dihasilkan.

Penelitian ini dapat menjadi pertimbangan penelitian selanjutnya untuk turut meneliti jenis serat yang dikonsumsi terhadap pola defekasi. Selain itu juga perlu dilakukan penelitian lebih lanjut dengan metode wawancara food recall yang lebih baik lagi dan juga perlu dilakukan penelitian tentang microbiota usus.

\section{DAFTAR PUSTAKA}

1. Overby KJ. Pediatric health supervision. Rudolph's fundamentals of pediatrics, edited by Abraham M. Rudolph and Robert K. Kamei. Chapter 1. First Ed. USA : Paramount Publishing Business and Professional Group. 1994. p:1-10

2. Miguel AS, Appleby PN, Spencer EA, Key TJ. Nutrition and lifestyle in relation to bowel movement frequency: a crosssectional study of 20630 men and women in EPIC-Oxford. Public Health Nutrition 2004; 7(1):77-83

3. Mayorga E et.al. Hubungan asupan serat makanan dan air dengan pola defekasi anak sekolah dasar di kota Bogor. Jurnal Gizi dan Pangan, Maret 2014. Bogor : Departemen Gizi Masyarakat, Fakultas Ekologi Manusia (FEMA), Institut Pertanian Bogor; 2014. p: 7-14

4. Dodge, John A. Functional disorders of the gastrointestinal tract. Pediatric gastroenterology and hepatology, edited by : Michael Gracey and Valerie Burke, Chapter IX. 3rd Ed. Victoria, Australia : Blackwell Scientific Publication; 1993. p: 880-890

5. Dorland. Kamus kedokteran Edisi30. Jakarta: EGC; 2008. p:480

6. Firmansyah A. Konstipasi pada anak. Buku ajar gastroenterologi-hepatologi Jilid 1. Edisi ke-1. Jakarta : Badan Penerbit IDAI; 2010. p:201-214

7. Eswaran Shanti, Jane Muir, William D Chey. Fiber and functional gastrointestinal disorders. The American Journal of Gastroenterology Vol 108, May 2013 edition. p :718-725

8. “Dietary reference intakes for energy, carbohydrate, fiber, fatty acids, cholesterol, protein, and amino acids (macronutrients), Chapter 7 : Dietary, functional and total fiber" . US Department of Agriculture, National Agricultural Livrary and National Academy of Sciences, Institute of Medicine, Food, and Nutrition Board; 2005

9. Loening-Baucke V. Encopresis and soiling. Pediatr Clin N Am; 1996. p:279-298

10. Menteri Kesehatan Republik Indonesia. Jakarta : Peraturan Menteri Kesehatan Republik Indonesia Nomor 75 Tahun 2013 
Tentang Angka Kecukupan Gizi yang Dianjurkan Bagi Bangsa Indonesia.

11. Dietary Recommendation Intakes : Macronutrients. Instititute of Medicine, National Academics

12. Riset Kesehatan Dasar RISKESDAS 2013. Jakarta : Badan Penelitian dan Pengembangan Kesehatan Kementrian Kesehatan RI Tahun 2013

13. Monastyrsky K. What exactly are normal stools?. Available at www.gutsense.org/constipation/normal_stools.html Accessed 20 Januari 2015

14. Mahan LK, Escott SS. Krause's food and nutrition therapy. 12th ed. Philadelphia:Saunders El-sevier; 2008

15. Puspamika DMRN, Sutiari NK. Konsumsi serat pada anak sekolah dasar kota Denpasar. Community Health Vol. II. No.1. Januari 2014. hal : 133-140

16. Berdanier CD, Dawyer J, Feldman EB. Handbook of Nutrition and Food. 2nd Ed. Boca Raton: CRC Press; 2007. p: 570-573
17. Kedia S, Van Willigen J. Applied Anthropology : Domains of Application. California : Greenwood Publishing Group; 2005. p : 162-164

18. Dietitians of Canada. Food sources of soluble fibre. Avalable at www.dietitans.ca Accessed 17 June 2015

19. Mordic,J. List of High Fiber Foods,Soluble and Insoluble Fiber Chart.Available at www.healthytype.com/list-of-fiber-foodssoluble-and-insoluble-fiber-chart.html Accessed 17June 2015

20. Hemarajata P, Versalovic J. Effects of probiotics on gut microbiota : mechanisms of intestinal immunomodulation and neuromodulation. Therapeutic advances in gastroenterology. 2013. p:39-51

21. Gerristen J, et.al. Intestinal microbiota in human health and disease : the impact of probiotics. Genes \& Nutrition. Aug 2011. p: 209-240 